Bull. Fac .Agric., Cairo Univ. 67:181-191 (2016).

\title{
EFFECT OF SOWING DATE, FERTILIZERS AND BROOMRAPE CONTROL TREATMENTS ON FABA BEAN (VICIA FABA L.) PRODUCTIVITY.
}

\author{
(Received: 21.6.2016)
}

\author{
By \\ A.A.O. Fakkar, H. E.A. Ibrahim* and M. A. Raslan** \\ Weed Central Labratury, *Central Labratury For Design and Statistical analysis Reasearch \\ **Field Crops Reseach Institute, Agriculture Research Center, Giza, Egypt
}

\begin{abstract}
Two field experiments were carried out during two successive seasons (2013/2014 and 2014/2015) in naturally Orobanche infested soil at Shandaweel Research Station, Agricultural Research Center, Sohag Governorate. Studies were carried out to investigate the effect of two sowing dates (middle of October and first of November), three fertilizations (mineral fertilization at a rate of $20 \mathrm{~kg} \mathrm{~N} / \mathrm{fed}$, Farm yard manure at a rate of $20 \mathrm{~m}^{3}$ /fed and no fertilization) and five broomrape control treatments (glyphosate at a rate $50 \mathrm{~cm}^{3} / \mathrm{fed}+$ hand pulling once (H.P), glyphosate at a rate 75 $\mathrm{cm}^{3} / \mathrm{fed}+$ hand pulling once, glyphosate twice at a rate of $75+50 \mathrm{~cm}^{3} / \mathrm{fed}$, hand pulling twice and untreated) on broomrape control and faba bean productivity. The results showed that sowing date, first of November significantly reduced both the dry weight of broomrape as compared to the other sowing date (mid. of October). The decreasing percentage in weight of broomrape by sowing on the first of November was $23.54 \%$ as compared with the first sowing date (mid. of October). Sowing date mid. of October recorded the highest values of growth characters, yield and yield attributes. The mineral and organic fertilizers significantly reduced both the number and dry weights of broomrape compared with the control. Moreover, mineral fertilizer delayed shoot emergence above the soil. Also, the fertilizer recorded the highest values of growth characters, yield and yield attributes. Application of glyphosate once with a rate of $50 \mathrm{~cm}^{3}$ or (glyphosate one time with rate $75 \mathrm{~cm}^{3} /$ fed) glyphosate two times with a rate of $50 \mathrm{~cm}^{3}+75 \mathrm{~cm}^{3}$ significantly decreased the number, dry weight of proomrape and delayed its emergence compared with the untreated plots. Hand pulling twice was the most significant treatment in increasing yield and yield attributes. Moreover, hand pulling twice and glyphosate two times 50+75 caused faba bean seed yield increase of 75.8 and $72.2 \%$ respectively. Meanwhile applying glyphosate once at a rate of $50 \mathrm{~cm}^{3}$ and once at rate of $75 \mathrm{~cm}^{3}$ resulted in an increase of 69.6 and $63.2 \% 9$ in faba bean seed yield; respectively, over the untreated control treatment. Maximum seed yield was obtained with sowing on mid. of October, adding mineral fertilization and the application of glyphosate two times 50+75. There was a strong negative correlation between faba bean seed yield and the number and weight of Orobanche infestation $/ \mathrm{m}^{2}\left(\mathrm{r}=-0.548^{* *},-0.528 * *\right.$ respectively). Also, it is clear that these treatments which had low Orobanche infestation had good growth patterns and hence showed high seed yield
\end{abstract}

Key words: Orobanche crenata, faba bean, glyphosate, sowing dates.

\section{INTRODUCTION}

Broomrape is considered one of the most serious agricultural problems in Egypt, Mediterranean countries and different parts of the world, causing severe damage to legume crops (Mauromicale et al., 2000). Egyptian broomrape (Orobanche aegyptiaca pers.) is a parasite that attacks the roots of many dicotyledonous crops including legumes. It draws carbon, nutrients and water through haustoria, which connect the parasite with the host's vascular system. Broomrape infestation causes reductions in crop yield, adversely affecting crop quality and results in a loss of cultivated land area (Nandula, 1998). Among the most affected crops are legumes. Management of broomrape is difficult because of its close association with the host. Broomrapes are obligate holophrastic weeds that cause severe damage to the most important vegetable and 
field crops in the Mediterranean region and the Middle East. Control of these parasites is difficult because broomrape produces hundreds of thousands of minute seeds that are highly persistent to the soil conditions and can easily transfered to new areas. Methods of control include agricultural practices (such as hand weeding, tillage, crop rotation and sowing dates) and chemical control. Planting time is the major factor affecting development, source of sink relationship and assimilation in faba bean plants. Planting time is crucial in many farming systems to avoid frost, drought, pests or diseases, which may occur early or late in the growing season. Late sowing may result in severe insect and disease attack (Sahile et al., 2008). Mekky et al. (2003) reported that sowing faba bean on the $15^{\text {th }}$ and $30^{\text {th }}$ of November decreased broomrape infestation by 44.8 and $92 \%$, respectively, as compared with the $1^{\text {st }}$ of November in both growing seasons, in association with increasing seed yield by 6.55 and $27.7 \%$, respectively. Shad et al. (2011) reported that the sowing date up to the $4^{\text {th }}$ of October produced higher yield, thereafter yield decreased as sowing was delayed and yield recorded for crop sown on the $27^{\text {th }}$ of December. (El-Metwally et al., 2013). Sowing seeds at $10^{\text {th }}$ December with spraying glyphosate or imazapic (three times/each) reduced both the number and dry weights of broomrape.

Most success in controlling broomrape has been achieved with using glyphosate. Rates of 0.2 to $0.3 \mathrm{~kg} \mathrm{ha}^{-1}$ gave good selective control when sprayed 6 weeks after sowing. Glyphosate is thought to translocate through the host phloem to broomrape attachments on the host roots and then exert its toxic effect (Nandula, 1998). Nassar and Mekky (2002) reported that controlling broomrape by applying glyphosate three times (7, 10 and 13 weeks) after sowing decreased the number and dry weight of broomrape spikes by 98.8 and $99 \%$, as compared with the untreated plots in both seasons, successively. Application of glyphosate two or three times at the rate of $75 \mathrm{~cm} 3 /$ fed gave 99.1 and $97.8 \%$ reduction of broomrape and increased seed yield by 149.5 and $141.5 \%$ as compared with the untreated plots in both seasons under investigation successively. Messiha et al. (2004) reported that the post-emergence application of the low rate of glyphosate $(25 \mathrm{ppm})$ substantially controlled broomrape parasitism in peas, by reducing the number and fresh and dry weights as compared with infected control. Al-Marsafy et al. (2000 and 2001) studied the feasibility of hand pulling as alternative or complement with glyphosate. This method can only be recommended for low Orobanche infestations to prevent further increases of the parasite populations and seed bank. Ismail (2013) stated that application of glyphosate alone or as complement with hand pulling gave higher reduction in the number and weight of broomrape by 97.1, 97.1, 97.0, and 97.3\%, respectively, as compared with untreated chick, and improved seed yield by 75.6 and $72.1 \%$, respectively.

El-Metwally et al., (2013) reported that glyphosate application three times significantly increased seed yield over the unweeded check by $85.1 \%$. While, the maximum seed yield was recorded with crop sown at the $25^{\text {th }}$ of November and at $10^{\text {th }}$ November with the application of glyphosate (at $90 \mathrm{~g}$ a.i./ha) or imazapic (at the rate of $50 \mathrm{~g}$ a.i./ha) three times. Eventually, it could be concluded that sowing dates on $25^{\text {th }}$ November with application of glyphosate or imazapic three times was the best combination for enhancing yield and its attributes. El-Rokiek et al (2015) found that the maximum yield was obtained with the addition of ammonium sulfate to glyphosate at $37.5 \mathrm{ml} / \mathrm{fed}$ compared with the infected control

Ismail (2013) revealed that adding (10 and $20 \mathrm{~kg} \mathrm{~N} / \mathrm{fed}$ ) reduced Orobanche infestation by 22.3 and $43.9 \%$, respectively. Meanwhile, obvious improved seed yield by 14.9 and 13.1 $\%$, respectively, than unfertilized plots. Organic manure improved of seed yield by 1.5 and 4.2 $\%$, respectively, than without manure.

Kasasian (1973) found that manure and Nfertilizers can play an important role in reducing the level of broomrape infestation. High nitrogen application reduced development of Egyptian broomrape and crenate broomrape. Low fertility is considered to be an important factor associated with severe infestation of fields by broomrape . Gharib(1973), Kukula and Masri (1984) reported that $40 \mathrm{~kg} / \mathrm{ha}$ ammonium nitrate were able to reduce the number of emerged Orobanche shoots and increased the yield of faba bean. The effects of $\mathrm{N}$ from different sources had different inhibitory effect on broomrape seeds (Abu-Irmaileh, 1994 and Nandula et al., 1996).

The present study aimed to estimate the magnitude of contribution of the use of sowing date, fertilizers and hand pulling and selective herbicides alone or in integration with each other 
for controlling broomrape, and increasing yield and its components in faba bean.

\section{MATERIALS AND METHODS}

Two field experiments were conducted at Shandaweel Research Station, Sohag Governorate during 2013/14 and 2014/15 seasons in naturally infested soil with Orobanche. Soil texture of the experimental plots in both seasons was sandy loam (Table 1). Each experiment included thirty six treatments which were a combination of three $\mathrm{N}$ rates, three manure treatments and six Orobanche control treatments using a split split plot design in three replications as follows :-

\subsection{Main plots: (sowing dates)}

2.1.1. Mid of October

2.1.2. First of November

\subsection{Sub plots: (fertilization):}

2.2.1. Mineral fertilization was applied as ammonium sulphate $(33.5 \% \mathrm{~N})$ at a rate of 20 $\mathrm{kg} \mathrm{N} /$ fed before the first and the second irrigations of faba bean.

2.2.2. Farm yard manure (Table 2 ) at a rate of 20 $\mathrm{m}^{3} /$ fed was applied before sowing

\subsubsection{Unfertilization}

\subsection{Sub sub plots: Orobanche control treatments}

2.3.1. Glyphosate $\{\mathrm{N}-$ (phosphonomethyl) glycine \} known commercially as Roundup (48\% WSC) at $50 \mathrm{~cm}^{3} / \mathrm{fed}$, applied once at the beginning of flowering of faba bean plant followed by one hand pulling.

2.3.2. Glyphosate used once with rate $75 \mathrm{~cm}^{3}$ /fed at the beginning of the flowering stage followed by one hand pulling.

2.3.3. Glyphosate used two times with equal rate of $50 \mathrm{~cm}^{3}$ /fed at the beginning of the flowering stage $+75 \mathrm{~cm}^{3} / \mathrm{fed}$ at 21 days after the first application

2.3.4. Hand pulling twice.

2.3.5. Untreated (control).

Seeds of the faba bean (Misr1 cultivar) were used in both seasons with a rate of 35 $\mathrm{kg} /$ feddan. The recommended agricultural practices of faba bean production were adopted. Plot area was $10.5 \mathrm{~m}^{2}$ included five ridges $3.5 \mathrm{~m}$ length and $60 \mathrm{~cm}$ apart. The herbicidal treatments were sprayed with a knapsack sprayer with one nozzle boom using , 200 liters/fed of water.

\subsection{Data recorded}

\subsubsection{Broomrape}

Before faba bean harvest, the number of broomrape spikes $/ \mathrm{m}^{2}$ directly was counted and the dry weight of broomrape $/ \mathrm{m}^{2}$ was recorded.

\subsubsection{Faba bean yield and its components}

At harvest in mid April, samples of ten faba bean plants were collected randomly from the central rows of each plot to record the following traits: plant height $(\mathrm{cm})$, number of branches/plant, number of pods/plant, weight of pods (g/plant), seed weight (g/plant), 100-seed weight (g) and seed yield ( $\mathrm{ard} / \mathrm{fed}$ ) were recorded from the whole plot.

\subsection{Statistical analysis}

The data obtained were subjected to analysis of variance (ANOVA). Since the trend of the results was similar in both seasons, the combined analysis of the data was carried out (Gomez and Gomez, 1984). Bartlet test of homogeneity for error indicated that the variance of the data of both seasons was insignificant; Treatment means were compared using the least significant differences test (LSD) at the 0.05 level. Simple correlation coefficients among the studied traits were calculated according to Draper and Smith (1966).

\section{RESULTS AND DISCUSSION 3.1.The effects on broomrape \\ 3.1.1.Effect of sowing date}

The results in Table (3) indicated that for the number of broomrape spikes no significant differences were observed between the two sowing dates but the dry weights of broomrape spikes were significantly affected by the different sowing dates. The second sowing date on first of November reduced the number, weight and dates of emersion of broomrape as compared with the first sowing date (mid.October). The decrease percentage in the weight of broomrape by sowing dates on the first of November was $23.54 \%$ as compared with the other sowing date (mid. October). These results might be due to the increase in temperature, which encourages the earlier germination of broomrape seeds than the second sowing date (Mekky et al., 2003 and El- Metwally et al., 2013).

\subsubsection{Effect of fertilization}

The results in Table (3) indicated that the number and weight of broomrape spikes were significantly affected by the different fertilizers. The mineral fertilizer reduced both the number and weight of broomrape spikes followed by organic fertilizer as compared with the unfertilized plots. This might be due to nitrogenous fertilizers, which reduced broomrape 


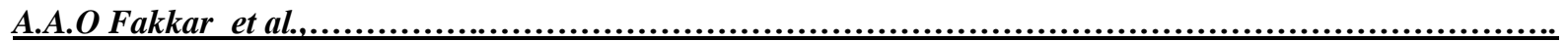

Table (1): Chemical analysis of the soil 2013/14 and 2014/15 seasons.

\begin{tabular}{|c|c|c|c|c|c|c|c|}
\hline $\begin{array}{c}\text { Chemical } \\
\text { Seasons }\end{array}$ & Soil texture & O.M & $\mathbf{p H}$ & $\mathbf{C a C o 3}$ & $\mathbf{N}$ & $\mathbf{P}$ & $\mathbf{K}$ \\
\hline $2013 / 14$ season & \multirow{2}{*}{ Sandy loam } & 0.6 & 7.9 & 7.50 & 14 & 18 & 12 \\
\cline { 3 - 9 } & & 0.8 & 7.7 & 7.55 & 13 & 17 & 13 \\
\hline
\end{tabular}

Table (2): Chemical analysis of farm yard manure (FYM) applied in the experiment.

\begin{tabular}{|l|l|l|l|l|l|l|l|}
\hline Component & $\begin{array}{l}\text { Organic } \\
\text { matter \% }\end{array}$ & $\mathbf{p H}$ & $\begin{array}{l}\text { Total } \\
\text { nitrogen } \\
\text { \% }\end{array}$ & $\begin{array}{l}\text { Organic } \\
\text { carbon \% }\end{array}$ & $\begin{array}{l}\text { C/N } \\
\text { ratio }\end{array}$ & P \% & K \% \\
\hline $\begin{array}{l}\text { Fertilizer } \\
\text { of (FYM) }\end{array}$ & 20.02 & 7.7 & 0.49 & 11.61 & 23.69 & 0.24 & 1.10 \\
\hline
\end{tabular}

Table(3): Effect of sowing dates, fertilization and weed control treatments on broomrape control and growth of faba bean plants (average of the two seasons).

\begin{tabular}{|c|c|c|c|c|c|}
\hline \multirow{2}{*}{ Characters } & \multicolumn{3}{|c|}{ Broomrape characters } & \multicolumn{2}{|c|}{ Growth characters } \\
\hline & $\begin{array}{c}\text { No. of } \\
\text { spikes/ } \\
\mathbf{m}^{2}\end{array}$ & $\begin{array}{c}\text { Weight } \\
\text { of } \\
\text { Spikes } \\
\text { (g/m2) }\end{array}$ & $\begin{array}{c}\text { Days of } \\
\text { emergence }\end{array}$ & $\begin{array}{c}\text { Plant } \\
\text { height } \\
\text { (cm) }\end{array}$ & $\begin{array}{c}\text { Number of } \\
\text { branches/plant }\end{array}$ \\
\hline \multicolumn{6}{|c|}{ Sowing dates } \\
\hline Middle of October & 9.93 & 40.82 & 127.83 & 125.93 & 3.15 \\
\hline First of November & 7.79 & 31.21 & 115.99 & 120.85 & 2.84 \\
\hline F test & NS & $*$ & $* *$ & $*$ & $*$ \\
\hline LSD at 0.05 & & 3.44 & 0.104 & 3.39 & 0.11 \\
\hline \multicolumn{6}{|c|}{ Fertilization } \\
\hline Mineral & 6.55 & $26.83^{\prime}$ & 123.48 & 120.74 & 2.73 \\
\hline Organic & 8.85 & 36.65 & 116.47 & 121.08 & 2.67 \\
\hline Unfertilized & 11.18 & 44.55 & 125.78 & 128.35 & 3.58 \\
\hline F test & $* *$ & $* *$ & $* *$ & $*$ & $*$ \\
\hline LSD at 0.05 & 1.19 & 3.83 & 4.12 & 4.26 & 0.08 \\
\hline \multicolumn{6}{|c|}{ Orobanche control } \\
\hline Glyphosate $50+$ H.P & 4.44 & 18.74 & 121.28 & 126.42 & 3.18 \\
\hline Glyphosate 75+H.P & 5.75 & 22.99 & 120.69 & 123.54 & 3.19 \\
\hline Glyphosate $50+75$ & 11.03 & 44.85 & 120.64 & 126.93 & 3.10 \\
\hline Hand pulling twice. & 6.42 & 26.75 & 121.58 & 127.12 & 3.04 \\
\hline Untreated (control). & 16.67 & 66.74 & 125.36 & 112.94 & 2.47 \\
\hline F test & $* *$ & $* *$ & $* *$ & $* *$ & $* *$ \\
\hline LSD at 0.05 & 1.12 & 4.64 & 1.54 & 2.44 & 0.070 \\
\hline
\end{tabular}

transformed to $\log (\mathrm{x})$

seed germination and radicle length of the germinated seedings (Pieterse, 1991). Nitrogen from different sources had different inhibitory effects. The effect could be due to a direct interaction with the metabolism of broomrapes by altering the osmotic balance (Ernst, 1988), since high nitrogen supply would reduce the uptake of potassium for which the parasite has a high demand (Welte and Wemer, 1962 and Ernst, 1988). The present results are in line with those reported by Pieterse (1991) and Demirkan and Nemli (1994).

3.1.3. Effect of broomrape control treatments

As shown in Table (3) glyphosate once at a rate of $50 \mathrm{~cm} 3 / \mathrm{fed}$ +hand pulling once (H.P) or glyphosate once at a rate of $75 \mathrm{~cm}^{3} /$ fed thand pulling once were very effective in controlling broomrape.A decrease in the number and dry weight of broomrape spikes was recorded as 
compared with glyphosate two times at a rate of $50 \mathrm{~cm}^{3}+75 \mathrm{~cm}^{3} / \mathrm{fed}$, hand pulling twice and untreated (control).

The reductions in the dry weight of broomrape spikes were highly significant. The reduction percentage of broomrape dry weight by spraying glyphosate once at a rate of $50 \mathrm{~cm}^{3}$ /fed+H.P or glyphosate once at a rate of 75 $\mathrm{cm}^{3} /$ fed+H.P or glyphosate two times with equal rate of $50 \mathrm{~cm}^{3}+75 \mathrm{~cm}^{3}$ and hand pulling twice were $71.9,65.5,32.8$ and $59.5 \%$, respectively as compared with the untreated check treatments. The current results indicated that no significant differences were observed between glyphosate one time with a rate of 50 $\mathrm{cm}^{3}+$ H.P and (glyphosate one time with a rate of $75 \mathrm{~cm}^{3}+$ H.P on the dry weight of broomrape spikes ; they have similar effect.

The above results are in agreement with those of Mekky et al. (2003), Ghalwash et al. (2008), Ghannam et al. (2012) and El-Metwally et al.(2013) who reported that the action of glyphosate on broomrape is attributable to its selective accumulation in the young parasite plant up to a level four times as high as that in faba bean host root three days after spraying.

\subsubsection{Effect of the interaction}

The interaction among sowing dates, fertilization and broomrape control treatments significantly affected the number and dry weight of broomrape spikes (Fig. 1 and 2). Sowing date on the first of November, using mineral fertilizer and spraying glyphosate once at a rate of $50 \mathrm{~cm}^{3}$ reduced both the number and dry weight of broomrape as compared with the other treatments. Meanwhile, the highest value of weed infestation was recorded in the unfertilized check treatment when sowing was on the middle of October and untreated weed control.

This explains the integrated role of both delayed sowing date and glyphosate treatment in broomrape control which enables faba bean to tolerate weed parasitism. These results are in good harmony with those reported by Mekky et al. (2003), Khalil et al. (2010), Kawochar et al. (2011) and El-Metwally et al. (2013).

\subsection{The effects on faba bean growth \\ 3.2.1. Effect of sowing dates}

Significant variations were observed between the different treatments regarding their influence on the growth characters of faba bean plants including plant height, the number of branches/plant after 110 days from sowing as well as on the plant height at harvesting stage (Table 3). The maximum values of the previously mentioned characters were obtained at the sowing date on the middle of October. These results may be due to the favorable environmental conditions to germination of faba bean seeds and long growing season for the early sowing. Similar results were reported by Turk and Tawaha (2002), Khalil et al. (2011), Kawochar et al. (2011) and Shaban et al. (2013) 3.2.2.Effect of fertilization

Significant variations were observed between the different fertilization treatments regarding their influence on the growth characters of faba bean plants including plant height and the number of branches/plant after 110 days from sowing as well as on plant height at harvesting stage (Table 3). The maximum values of the previous mentioned characters were obtained for the unfertilized. However, the lowest values were recorded by the mineral fertilizer. The results also indicated that there are no significant differences between mineral and organic fertilizer. Similar results were reported by Shaban et al. (2013).

\subsubsection{Effect of broomrape control treatments}

Table (3) shows that the application of hand pulling twice, glyphosate two times and glyphosate one time+ hand pulling significantly increased plant height. The untreated check produced the lowest values of growth characters of faba bean plants. These results coincide with those reported by Mekky et al. (2003), Ghalwash et al. (2008) and El- Metwally et al. (2013)

\subsection{The effect on yield and its attributes \\ 3.3.1. Effect of sowing dates}

Faba bean yield and its attributes were significantly affected by the different dates of sowing (Table 4). The best results recorded for the different characters (including the No. of pods/ plant, pod weight / plant , Seed weight seed, 100 seed weight, yield ardab/fed) were for sowing on the middle of October. The high yield yield from the early planting might be due to the fact that the plants had sufficient longer vegetative period and better utilization of water and nutrients. The reduction in yield in the second sowing date may be due to poor growth, shorter seed filling duration and maturity period, less number of fruiting nodes and pods/ plant and minimum seeds/ pod (Sahile et al. 2008).

Effect of fertilization:

Significant variations were observed between the different fertilization treatments regarding their influence on the yield and its attributes of faba bean plants (Table 4). The maximum yield values of the previous 


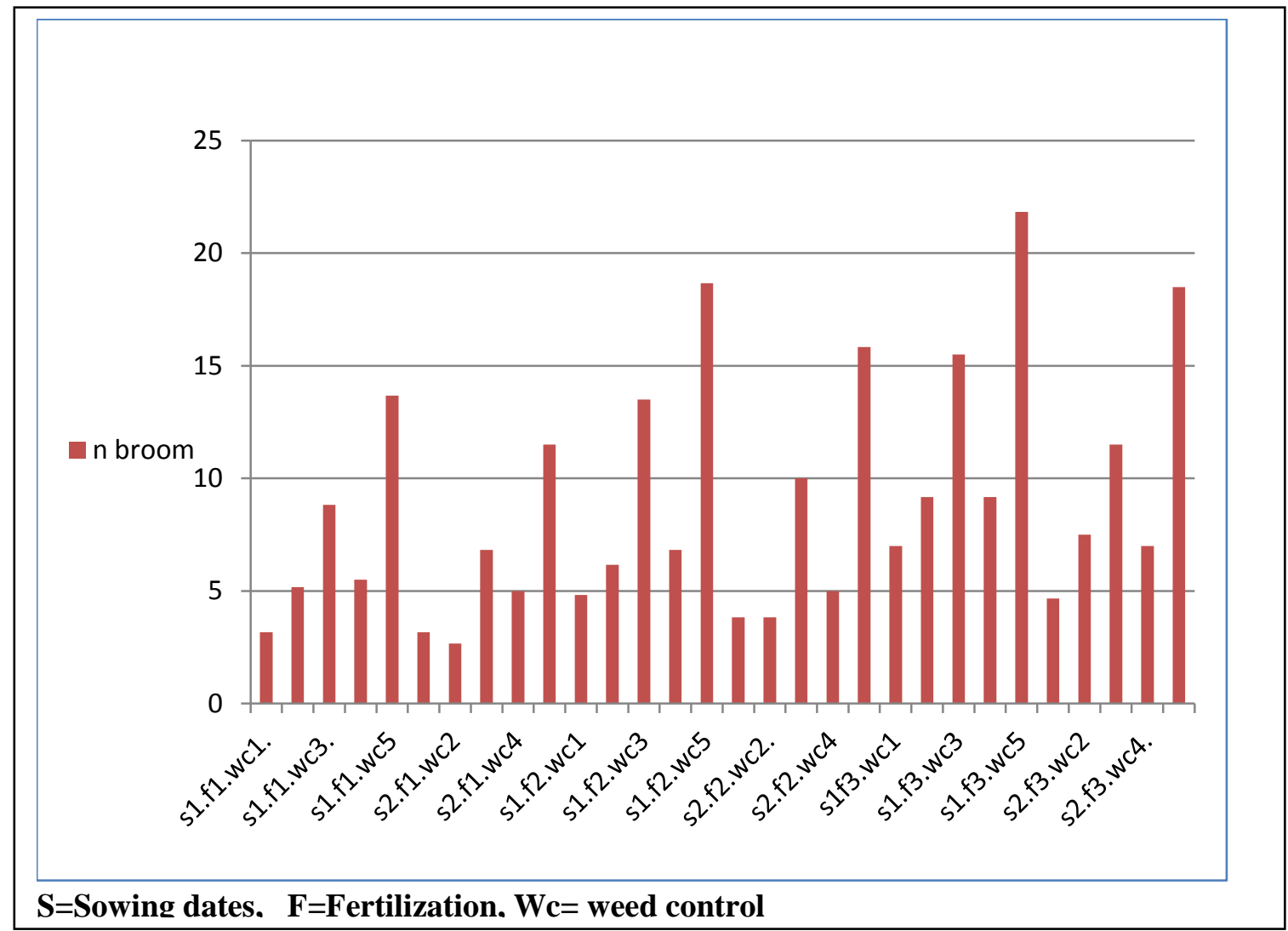

Fig. (1): Number of broomrape spikes at harvest $/ \mathrm{m}^{2}$ as influenced by the interaction between sowing dates and weed control treatments (combined data across 2013 /2014 and 2014/2015 seasons).

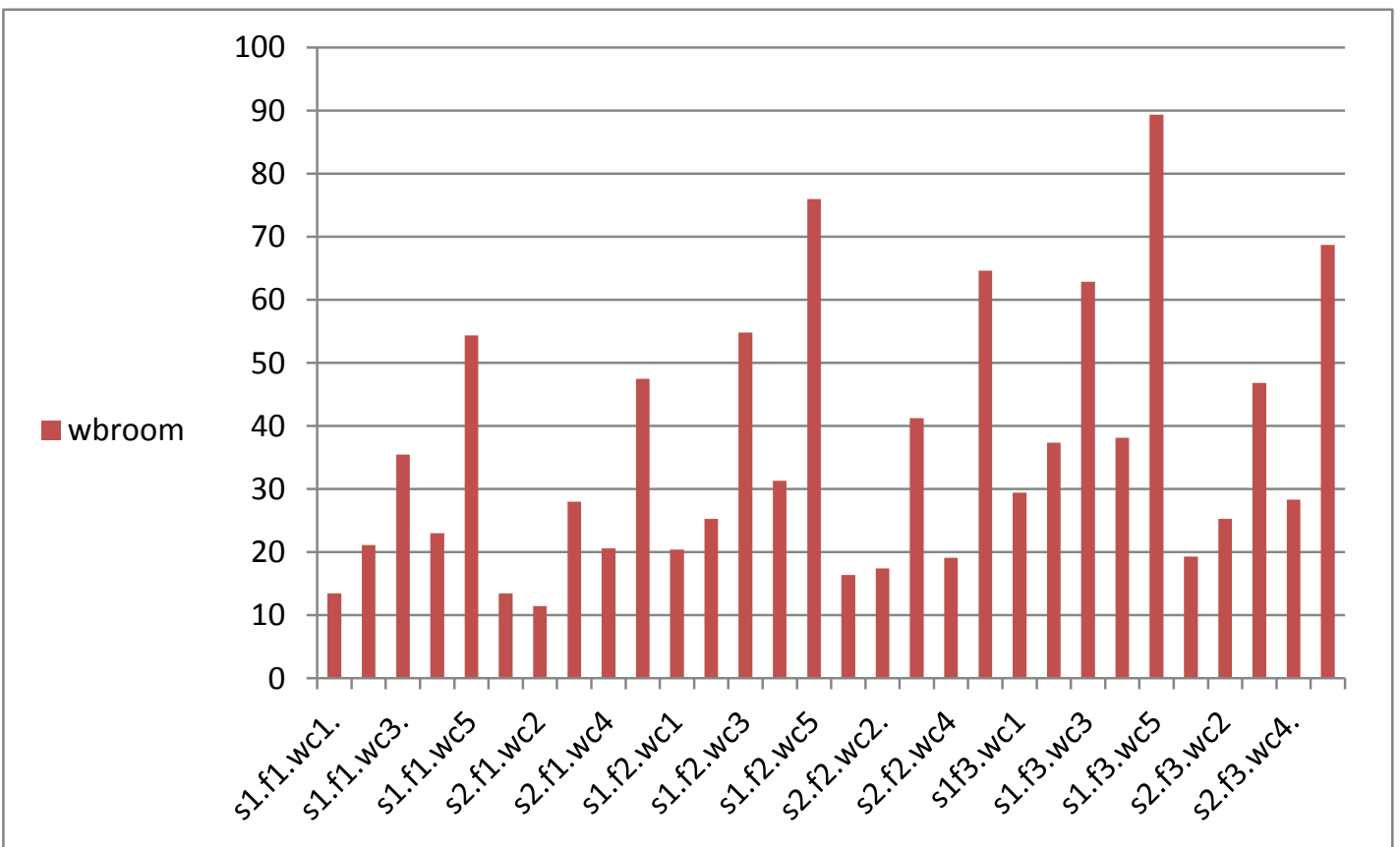

$\mathrm{S}=$ Sowing dates, $\mathrm{F}=$ Fertilization. $\mathrm{Wc}=$ weed control

Fig. (2): Weight of broomrape spikes at harvest $/ \mathrm{m}^{2}$ as influenced by the interaction between sowing dates, fertilization and weed control treatments (combined data across 2013 /2014 and 2014/2015 seasons). 
Table (4): Effect of sowing date, fertilization and weed control treatment on yield and yield attributes of faba bean plants (average of the two seasons).

\begin{tabular}{|c|c|c|c|c|c|}
\hline Treatments & $\begin{array}{l}\text { No. of } \\
\text { pods/ } \\
\text { plant }\end{array}$ & $\begin{array}{c}\text { Pod } \\
\text { weight / } \\
\text { plant } \\
\text { (g) }\end{array}$ & Seed weight & $\begin{array}{l}100 \text { seed } \\
\text { weight }\end{array}$ & $\begin{array}{c}\text { Yield } \\
\text { ardab/fed }\end{array}$ \\
\hline \multicolumn{6}{|c|}{ Sowing dates } \\
\hline Middle of October & 26.43 & 68.68 & 59.20 & 71.89 & 5.75 \\
\hline First of November & 24.41 & 57.68 & 47.24 & 64.86 & 4.87 \\
\hline F test & $*$ & $*$ & $*$ & $*$ & $*$ \\
\hline LSD at 0.05 & 0.66 & 4.90 & 4.13 & 5.19 & 0.20 \\
\hline \multicolumn{6}{|c|}{$\begin{array}{l}\text { Fertilization } \\
\end{array}$} \\
\hline Mineral & 25.47 & 60.42 & 48.75 & 65.77 & 5.45 \\
\hline Organic & 23.74 & 61.49 & 52.87 & 68.53 & 5.48 \\
\hline Unfertilized & 27.06 & 67.64 & 58.03 & 70.82 & 5.02 \\
\hline F test & $* *$ & $*$ & $* *$ & $* *$ & $* *$ \\
\hline LSD at 0.05 & 1.18 & 3.80 & 1.57 & 0.98 & 0.19 \\
\hline \multicolumn{6}{|c|}{ Orobanche control } \\
\hline glyphosate $50+$ H.P & 27.22 & 66.98 & 57.52 & 72.75 & 5.77 \\
\hline glyphosate $75+$ H.P & 26.62 & 66.89 & 58.11 & 72.55 & 5.55 \\
\hline glyphosate $50+75$ & 25.27 & 62.92 & 51.50 & 69.98 & 5.86 \\
\hline $\begin{array}{l}\text { Hand pulling } \\
\text { twice. }\end{array}$ & 26.86 & 68.00 & 58.23 & 73.03 & 5.98 \\
\hline Untreated (control). & 21.14 & 51.11 & 40.72 & 53.57 & 3.40 \\
\hline F test & $* *$ & $* *$ & $* *$ & $* *$ & $* *$ \\
\hline LSD at 0.05 & 1.01 & 2.48 & 2.24 & 1.95 & 0.21 \\
\hline
\end{tabular}

mentioned characters (5.48 ard/fed) were obtained by using the organic fertilizer followed by mineral fertilizer $(5.45 \mathrm{ard} / \mathrm{fed})$. Similar results were obtained by Ismail (2013).

\subsubsection{Effect of broomrape control treatments}

According to the results in Table (4), yield and yield components of faba bean were significantly affected by broomrape control treatment. Hand pulling twice was the most significant treatment in increasing No. of pods/ plant, pod weight/plant, seed weight, 100-seed weight and seed yield ardab/fed. Moreover hand pulling twice and glyphosate two times $50+75$ $\mathrm{cm}^{3} /$ fed caused seed yield increase by 75.8 and $72.2 \%$, respectively, Meanwhile applying glyphosate once at $50 \mathrm{~cm}^{3} / \mathrm{fed}+\mathrm{H} . \mathrm{P}$ and glyphosate once at $75 \mathrm{~cm} 3+$ H.P has achieved an increasing estimate by 69.6 and $63.2 \%$, respectively, over the untreated control. These results are due to the decrease in the number and dry weight of broomrape (Table 3). In this respect, Fayed et al. (2002) reported that there is a strong negative correlation between faba bean seed yield and the number and weight of Orobanche spikes $/ \mathrm{m}^{2}\left(\mathrm{r}=-0.548^{* *},-0.528 * *\right)$
(Table 5 ). The present study revealed that the chemical control of broomrape on faba bean can be achieved by using the herbicide glyphosate (48\% WSC) at two times at $50+75 \mathrm{~cm}^{3} / \mathrm{fed}$ which adequately enough to govern the number of broomrape emerging spikes in faba bean in addition hand pulling twice. Similar findings were reported by Shaban et al.(1986), Mekky et al. (2003), Ghalwash et al. (2008) and Bellido et al. (2009) and Al-Marsafy et al. (2000 and 2001).

\subsubsection{Effect of the interaction}

Analysis of the data revealed that sowing date, fertilization and broomrape control treatment interaction significantly affected seed yield ard/fed (Fig.3). Maximum seed yield was obtained with sowing on the middle of October, mineral fertilization with the application of glyphosate twice $(50+75)$. Meanwhile, the lowest seed yield was reported with sowing on the first of November, no fertilization with the untreated treatment. This explains the integrated role of both delayed sowing of faba bean and glyphosate herbicides in broomrape control. 
Table (5): Simple correlation coefficients among the number and weight of broomrape spikes and faba bean traits across two seasons.

\begin{tabular}{|c|c|c|c|c|c|c|c|c|c|}
\hline Traits & $\begin{array}{l}\text { Plant } \\
\text { height } \\
(\mathrm{cm}) \\
(\mathrm{PH})\end{array}$ & $\begin{array}{l}\text { Number } \\
\text { of } \\
\text { branches/ } \\
\text { plant } \\
\text { (N.br) }\end{array}$ & $\begin{array}{l}\text { Number } \\
\text { of pods/ } \\
\text { Plant } \\
\text { (N,pod) }\end{array}$ & $\begin{array}{l}\text { Weight } \\
\text { of pods } \\
\text { (g/plant) }\end{array}$ & $\begin{array}{l}\text { Seed } \\
\text { weight } \\
\text { (g/plant) }\end{array}$ & $\begin{array}{l}100 \\
\text { Seed } \\
\text { weight } \\
\text { (g) } \\
\text { (Seed) }\end{array}$ & $\begin{array}{l}\text { Seed } \\
\text { yield } \\
\text { ard/fed }\end{array}$ & 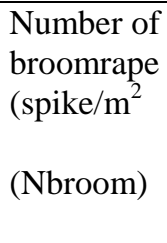 & $\begin{array}{l}\text { Weight } \\
\text { of } \\
\text { broomra } \\
\text { pe } / \mathrm{m}^{2} \\
\text { (w.broo } \\
\text { m) }\end{array}$ \\
\hline $\mathrm{PH}$ & 1 & & & & & & & & \\
\hline N.br & $0.52 * *$ & 1 & & & & & & & \\
\hline $\mathrm{N}$, pod & $0.58 * *$ & $0.451 * *$ & 1 & & & & & & \\
\hline W.pod & $0.59 * *$ & $0.53 * *$ & $0.48 * *$ & 1 & & & & & \\
\hline W.seed & $0.59 * *$ & $0.53 * *$ & $0.51 * *$ & $0.81 * *$ & 1 & & & & \\
\hline Seed & $0.58 * *$ & $0.44 * *$ & $0.53 * *$ & $0.74 * *$ & $0.78^{* *}$ & 1 & & & \\
\hline Yard & $0.53 * *$ & $0.29 * *$ & $0.50 * *$ & $0.59 * *$ & $0.62 * *$ & $0.72 * *$ & 1 & & \\
\hline Nbroom & $-0.18 *$ & -0.06 & $-0.30 * *$ & $-0.31 * *$ & $-0.27 * *$ & $-0.37 * *$ & $-0.55 * *$ & 1 & \\
\hline w.broom & $-0.19 *$ & -0.08 & $-0.31 * *$ & $-0.29 * *$ & $-0.26 * *$ & -0.38 & $-0.53 * *$ & $0.98 * *$ & 1 \\
\hline
\end{tabular}

*and**: Significant at 0.05 and 0.01 probability level, respectively

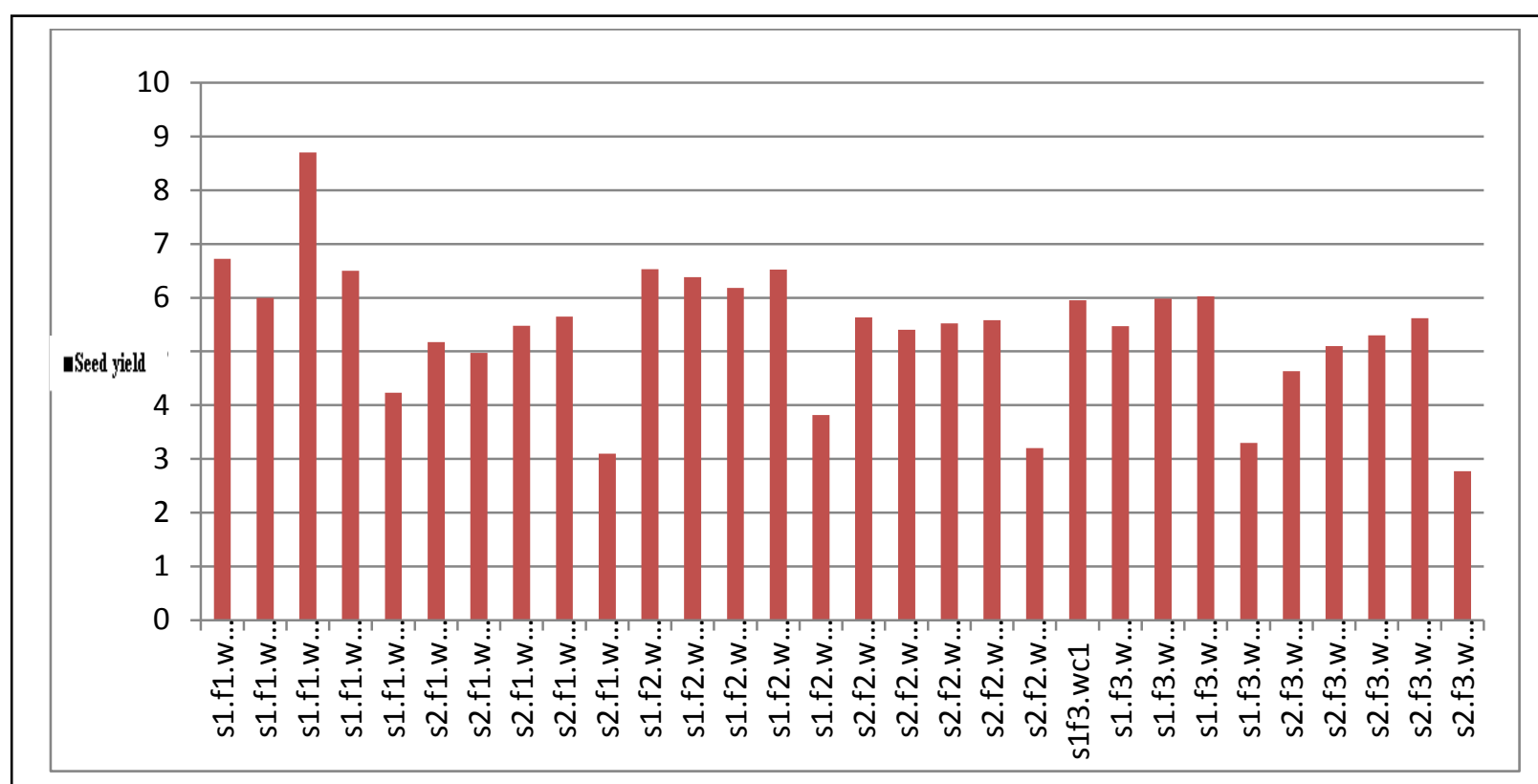

\section{S: Sowing dates, F: Fertilization, Wc: weed control}

Fig. (3): Seed yield (ard/fed) as influenced by the interaction between sowing dates, fertilization and weed control treatments (Combined data across 2013 /2014 and 2014/2015 seasons)

Such, integration could be forwarded to faba bean growers in infested areas by broomrape. The integration approach for broomrape control of faba bean was mentioned by Mekky et al. (2003) and Ghalwash et al. (2008).

\subsection{Correlation matrix}

The simple correlation coefficients among number and weight of broomrape spikes and faba beantraits are presented in Table (5). Results showed that there is a strong negative correlation between faba bean seed yield and the number and weight of Orobanche spikes $/ \mathrm{m}^{2}(\mathrm{r}=$ $-0.548 * *,-0.528 * *)$

\section{Conclusion}

It can be concluded from this study that sowing date, fertilization and broomrape control treatment interaction significantly affected faba bean seed yield (ard/fed) Maximum seed yield was obtained with sowing on the med of October and Mineral fertilization with the application of glyphosate two times $(50+75)$. Meanwhile, the lowest seed yield was reported with sowing on the first of November, no fertilization with the no broomrape control treatment. This explains the integrated role of both delayed sowing of faba bean and glyphosate herbicides in 
broomrape control. Such, integration could be forwarded to faba bean growers in infested areas by broomrape.

\section{REFERENCES}

Abu-Irmaileh B. E. (1994). Effect of various fertilizers on broomrape (Orobanche ramosa) infestation of tomatoes. p. 278284 in L. J. Musselman, A. D. Worsham, and R. E. Eplee, (eds.) Proc. Second. Int. Symp. Parasitic Weeds, N. C. State Univ., Raleigh, N.C.USA.

Al-Marsafy H.T., Hassanein E.E., Nassar A.N. and Fakkar A.A. (2000). Feasability of Orobanche hand pulling in faba bean fields as an alternative or complement to Orobanche chemical control. Nile Valley program for wild oats and other weeds control in winter cereals and some other winter crops. $8^{\text {th }}$ Ann. Coord. Meet., Cairo, Egypt, 3-7 Sept. pp. 297-202.

Al-Marsafy H.T., Hassanein E.E., Nassar A.N. and Fakkar A.A. (2001). Feasibility of Orobanche hand pulling in faba bean fields as an alternative or as a complement to chemical control . Nile Valley program for wild oats and other weeds control in winter cereals and some other winter crops. $9^{\text {th }}$ Ann. Coord. Meet. 2-6 sept. Cairo, Egypt. P.P. 282-285.

Bellido R.J.L., Vega J.B. and Bellido L.L. ( 2009). No- Tillage improve broomrape control with glyphosate in faba bean. Agron.J., 101(1): 1394-1399.

Demirkan H. and Nemli Y. (1994). Effects of some fertilizers on Orobanche ramosa L. on tomato. In proceeding of the third International and work-shop on orbanche and Related Striga Research eds.499-501. A. H. Pieterse, J.A.C. Verkleij, and S. J. ter Borg, Royal Tropical Institute, Amsterdam, The Netherlands.

Draper N.R. and Smith H. (1966). Applied Regression Analysis. John Wiley, New York, USA.

El-Metwally I.M, El-Shahawy T.A. and Ahmed M.A. (2013). Effect of sowing dates and some broomrape control treatments on faba bean. J. Appl. Sci. Res., 9(1): 197-204.

El-Rokiek Kowthar G, El-Metwally I. M., Messiha Nadia K. and Saad El-Din Samia Amin (2015) Controlling Orobanche crenata in faba bean using the herbicides Glyphosate and Imazapic with some additives I.nt.`1 J. ChemTech Res., 8(10): 18-26.

Ernst W. H. 0. (1988). Mineral nutrition of Nicotiana tabacum cv. Bursana during infection by Orobanche ramosa. in Proceedings of a workshop on biology and control of Orbanche ed. 80-85. S. L. Borg, ter LH/VPO, Wageningen,Netherlands.

Fayed M.A.B., Hamdi A., Mahmoud S.A. and Shaaban M. (2002). Performance of Orobanche control treatment in faba bean crop. Egypt J. Agric. Res., 80(2): 753-769.

Gharib M. S. (1973). Biological and economical aspects of the broomrapes, Orobanche spp., in Northern Iraq. p. 44-47 in Proc. Eur. Weed Res. Counc. Symp. Parasitic Weeds, Malta.

Ghalwash A.M., Soliman I E. and Khaffagy A.E. (2008). Performance of some faba bean (Vicia faba L.) cultivars under numerous broomrape (Orobanche crenata Forsk.) control treatment. J. Agric. Sci. Mansoura Univ., 33(4): 2439-2448.

Ghannam I., Al-Masri M. and Barakat R.( 2012). The effect of herbicides on the Egyptian broomrape (Orobanche aegyptiaca) in Tomato fields. Am. J. Plant Sci., 3: 346352.

Gomez K.A. and Gomez A.A. (1984). Statistical Procedures for Agricultural Research. John Wiley and Sons. Inc, New York,USA.

Ismail A.E.A. (2013). Integration between nitrogen, manure fertilizers, cultural practices and glyphosate on broomrape (Orobance crenata Forsk) control in faba beans (Vicia faba L.). Bull. Fac. Agric., Cairo Univ. 64 (4): 369- 378.

Kasasian L. (1973). Miscellaneous observations on the biology of Orobanche crenata and 0. aegyptiaca. Pages 68-75 in Proc. Eur. Weed Res. Counc. Symp. Parasitic Weeds, Malta.

Kawochar M.A., Ullah M.J., Salam M.A., Alam K.H. and Islam M.R. (2011). Effect of sowing time and fertilizer on growth attributes, dry matter partitioning and grain yield of faba bean. J. Expt. Biosci., 2(2): 17-24.

Khalil S.k., A. Wahab and Khan A.Z. (2011). Variation in leaf traits, yield and yield components of faba bean in response to planting dates and densities. Egypt, Acad. J. Biol. Sci., 2(1): 35-43. 
Khalil S., A. Wahab, A. Rehman,. Muhammad F, Wahab S.,. Khan A.Z, Zubair M., Shah M.K., Khalil I.H. and Amin R. (2010). Density and planting date influence phonological development assimilate partitioning and dry mater production of faba bean. Pak. J. Bot., 42(6): 3831-3838.

Kukula S . T. and Masri H. (1984). Integrated cultural practices and chemical control of Orobanche crenata in faba bean. Pages 256-261 in C. Parker, L. J. Musselman, R. M. Polhill, and A. K. Wilson, eds. Int. Symp. on Parasitic Weeds. Aleppo, Int. Ctr. for Agric. Res. in the Dry Areas. (ICARDA), Syria.

Mauromicale G., Restuccia G. and Marchese M. (2000). Germination response and viability of Orobanche crenata Forsk. Seeds subjected temperature treatment. Aust. J. Agric. Res., 51(5): 579-585.

Messiha N.K., Sharara F.A. and Elgayar S.H. (2004). Effect of glyphosate, fosamine ammonium and their mixture for control Orbanche crenata in peas (Pisum sativum). J. Agric. Sci. Mansoura Univ., 29(7): 3979-3991.

Mekky M.S., Yehia Z.R. and Nassar A.N.M. (2003). Effect of sowing date, varieties and glyphosate application on broomrape and yield of faba bean. Bull. Fac. Agric. Cairo; Univ., 54: 55-76.

Nandula V.K. (1998). Selective control of Egyptian broomrape (Orbanche egyptian Pers.) by Glyphosate and its amino acid status in relation to selected hosts. Ph.D. Thesis, Virginia polytechnic Institute and State University, Virginia, USA.

Nandula V. K., Foy C. L. and Westwood J. H. (1996). Environmental influences on germination of Orobanche. in: Advances in Parasitic Plant Research eds 409-416. M. T. Moreno, J. I. Cubero, D. Berner, D. Joel, and L. J. Musselman, Spain: Junta de An-dalucia. Pages 409-416.

Nassar A.N.M. and Mekky M.S. (2002). Effect of irrigation frequency and glyphosate application on broomrape control and yield of faba bean (Vicia faba L.). J. Agric. Sci. Mansoura Univ., 27(11): 71937202.

Pieterse A. H. (1991). The effect of nitrogen fertilizers on the germination of seeds of Striga hermonthica and Orobanche crenata. in: Progress Orobanche Research ed`s115-124. K.Wegmann and L.J. Musselman Eberhard- Karls Universitat,Tubengen, Germany.

Sahile S., Ahmed S., Fininsa C., Abang M.M. and Sakhuja P.K. (2008). Survey of chocolate spot (Botryty fabae) disease of faba bean (Vicia faba L.) and assessment of factors influencing disease epidemics in northern Ethiopia. Crop Protection, 27: 1457-1463.

Shaban Kh. A. , Khalil A. A. and Amira A. Mohamed (2013) Effect of sowing date and nitrogen, potassium fertilization on faba bean productivity in newly reclaimed saline soil of north sinai. J. Soil Sci. Agric. Eng., Mansoura Univ., 4 (9): 893 904.

Shaban S.H.A., El-Hattab A.H., Esmat A. and Abo El-Suoud M.R. (1986). Recovery of faba bean (Vicia faba L.) plants as affected by glyphosate. J. Agron. Crops Sci., 158: 294- 303.

Shad, K. Kh. ; Wahab, A. ; Amanullah, A. and Zaman, Kh (2011). Variation in leaf traits, yield and yield components of faba bean in response to sowing dates and densities. Egypt. Acd. J. Biolog. Sci., 2 (1): 35- 43.

Turk M.A. and Tawaha A.M. (2002). Impact of seeding rate, seeding date, rate and methods of phosphors application in faba bean (Vicia faba L. minor) in the absence of moisture stress. Biotec., Agron. Soc. Environ., 6(3): 171-178.

Welte E. and Wemer W. (1962). LonenAustauschversuche uber die Beeinflussung der Kationenaufnahmed er Pflanzen durch die Stickstoff-Form. Agrochem., 6:337-348. 


\section{تاثير ميعاد الزراعة والتسميد ومعاملات مكافحة الهالوك علي انتاجية الفول البلدي}

عادل احمد عمران فكار - هدي السيد العربي إبراهيم* ـ محمود احمد رسلان**

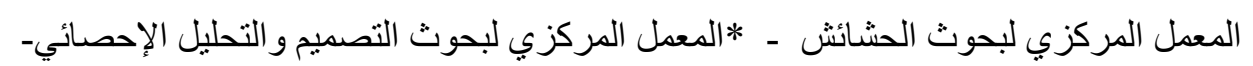

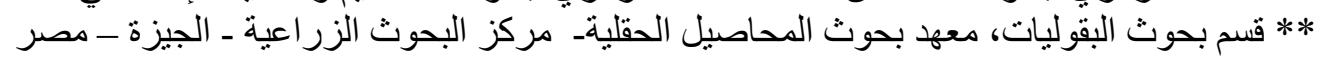

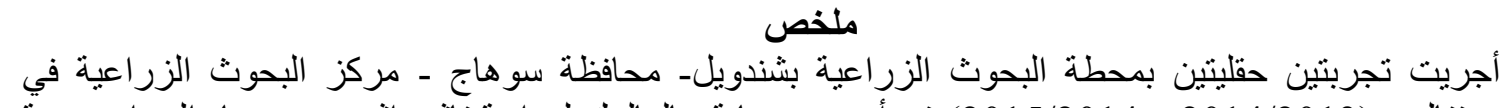

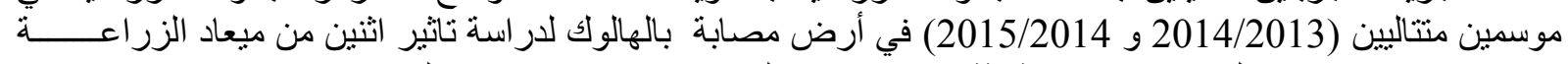

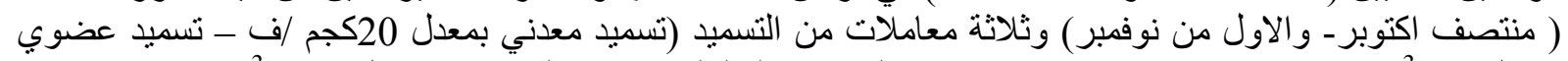

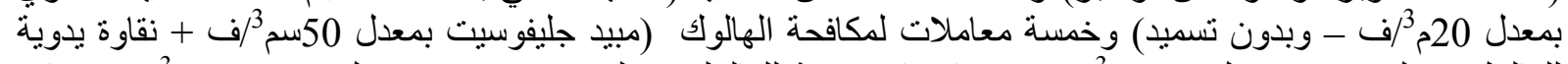

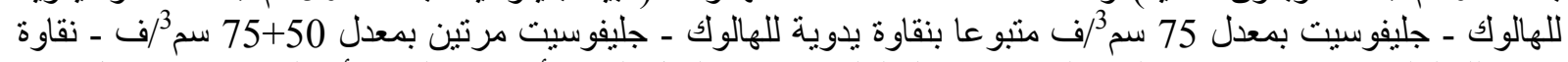

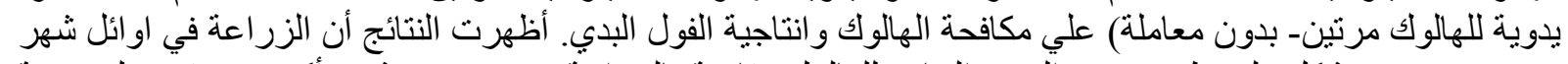

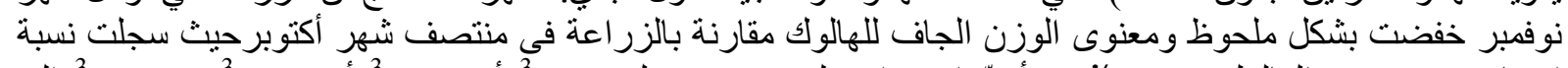

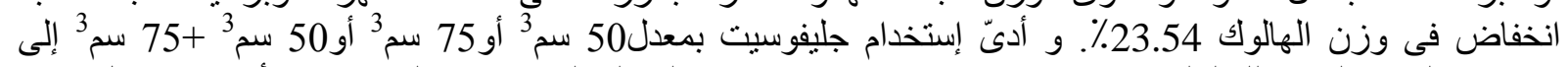

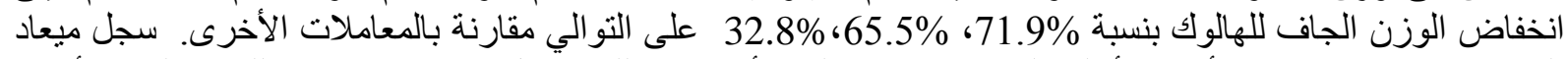

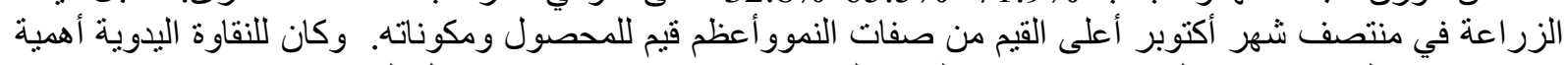

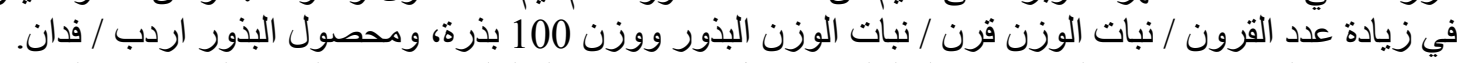

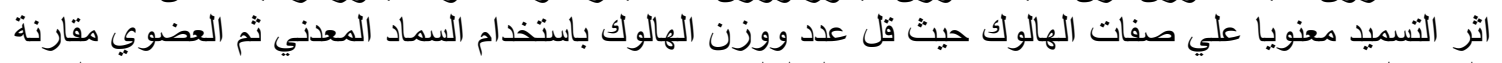

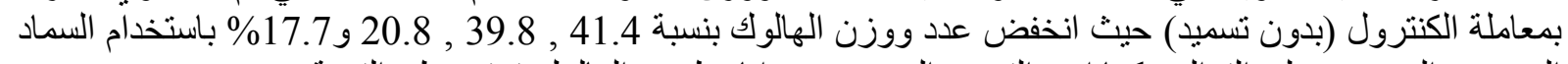

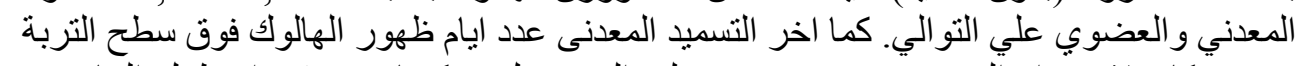

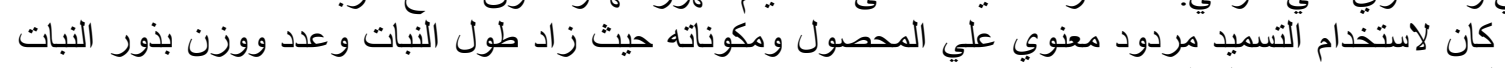

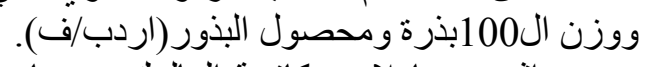

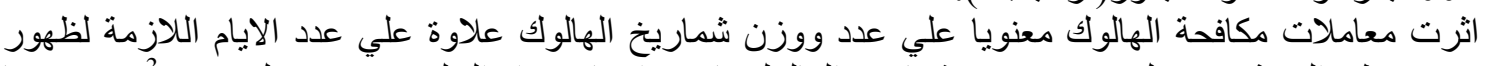

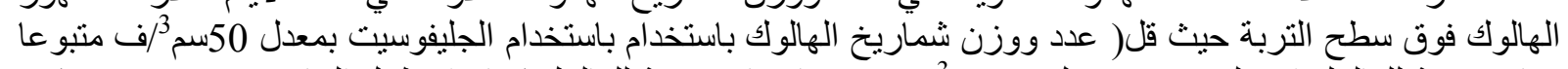

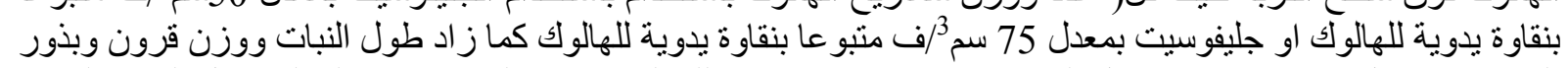

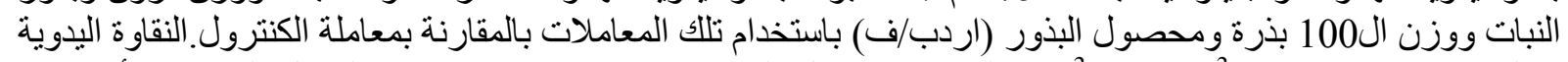

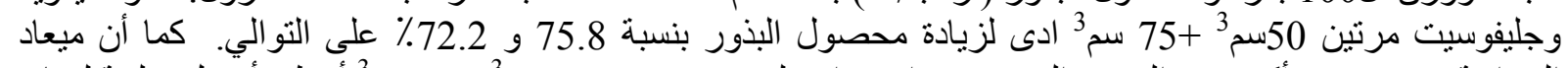

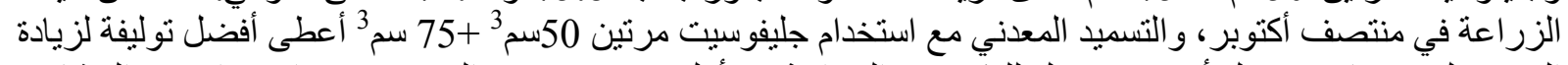

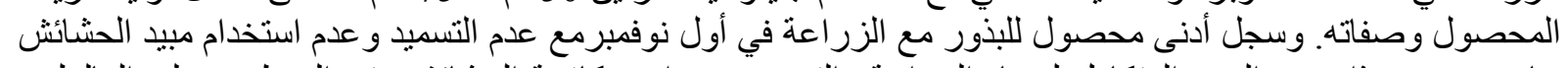

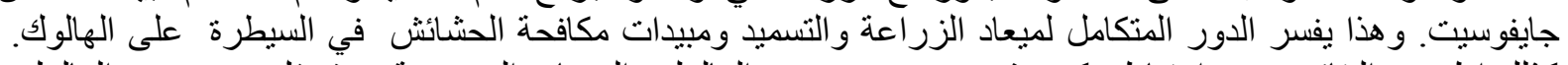

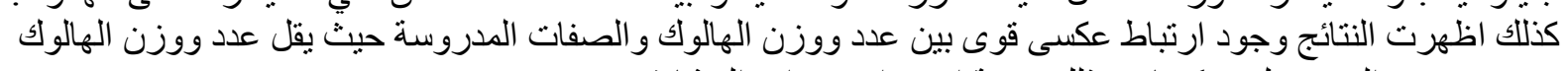

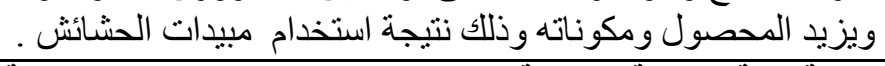

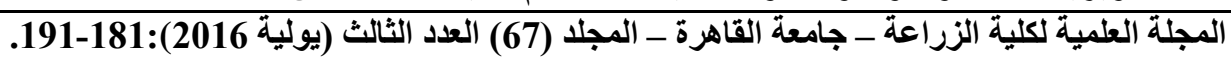

